\title{
Risky work: Accidents among Nepalese migrant workers in Malaysia, Qatar and Saudi Arabia
}

\author{
Pratik Adhikary ${ }^{1^{*}}$,Zoë A Sheppard ${ }^{1}$, Steve Keen ${ }^{1}$, Edwin van Teijlingen ${ }^{1-3}$ \\ ${ }^{1}$ Faculty of Health \& Social Sciences, Bournemouth University, Bournemouth, UK ${ }^{2}$ Manmohan Memorial Institute of Health Sciences, Tribhuvan University, Nepal ${ }^{3}$ \\ Nobel College, Pokhara University, Kathmandu, Nepal
}

Received:
05 March 2017
Revised:
19 April 2017
Accepted:
18 August 2017

\section{${ }^{*}$ Correspondence:} adpratik@hotmail.com Faculty of Health \& Social Sciences, 17-19, Christchurch Road Bournemouth University, Bournemouth, UK

\begin{abstract}
Background: Nepal is a growing supplier of migrant labour for factories in Malaysia and building sites in the Middle East. This study assessed the extent of workplace accidents among Nepalese migrant workers in Malaysia, Qatar and Saudi Arabia.
\end{abstract}

Methododology: A questionnaire survey was conducted at Nepal's main international airport with men who returned from working in Malaysia, Qatar and Saudi Arabia. The questionnaire was completed by 403 migrant workers from these three countries. Where possible the questionnaire was self-administered and interview-administered for those migrant workers with poor literacy skills. A logistic regression was conducted to identify factors associated with accidents at work and health risks perceived by migrant workers themselves.

Results: One in six (17\%) experienced accidents at work in their host country. This proportion is lower than that reported in previous studies of Nepali migrant workers. Age, country of work, doctor registration and perceived standard of work environment and accommodation are significantly associated with accidents at work.

Conclusion: To help improve Nepalese men's health and well-being whilst working abroad, host countries and the Government of Nepal should ensure that migrants hold health insurance. Mandatory pre-departure and arrival health and safety training is also recommended as a way to reduce risks to the health of migrant workers.

Keywords: Asia, host country, labour, risk, accidents, migrant workers, Middle East

Suggested citation: Adhikary P, Sheppard ZA, Keen S, van Teijlingen E. Risky work: Accidents among Nepalese migrant workers in Malaysia, Qatar and Saudi Arabia. Health Prospect. 2017;16(2):3-10.

\section{Introduction}

Work-related migration, like migration in general, is on the increase. The number of people living and working abroad continues to rise and there has been significant growth in temporary labour migration from Low Income Countries (LIC) to High Income Countries (HIC) (1). Several HIC-based studies (e.g. from Canada, Spain, Germany and the United States) indicate that immigrants are over-represented in physically demanding high-risk jobs including manufacturing, construction and farming $(2,3)$ and have higher rates of occupational injury than native-born workers $(3,4)$.

Currently, over a million Nepalese migrants, mostly from a rural background, work in Malaysia and the Middle East, mainly in semi-skilled and unskilled jobs (5). Most temporary migrant workers in these countries work in risky industries such as construction, manufacturing and farming $(6,7)$. Some of the key reasons for the migration of these temporary workers include employment opportunities abroad and associated high exchange rates $(7,8)$. Concurrent with the increase in foreign migrant workers, there has been a significant rise in the remittances Nepal receives $(5,9)$. For example, in 2013 Nepal received US $\$ 4.5$ billion remittances from migrant workers, almost equivalent to a quarter of its national income (10), but in 2015 this had risen to US $\$ 6.6$ billion (11).

Published studies indicate that migrant workers worldwide face risks of workplace accidents and other lifestyle-related risks, such as the use of tobacco and alcohol $(7,12)$. This wider literature also shows that construction and manufacturing industries are among the most dangerous sectors to work-in globally $(13,14)$. Poor work environment, including an absence of safety measures and equipment are the leading causes of accidents and injuries [15-17]. Therefore, migrant construction and factory workers, often illiterate, face a double burden of working in a dangerous sector from a disadvantaged position. 
Media reports have estimated that around 600 Nepalese workers died abroad in 2009 and over 800 in 2010 (17). Most of the deaths occurred in the Middle East, with 323 deaths in Saudi Arabia, 192 in Qatar and 84 in the United Arab Emirates (UAE) and 84 in Malaysia. It has been reported that most deaths are due to work-related hazards, road accidents and frustration among workers leading to suicide (18). A more recent media report has highlighted that over 1,300 Nepali migrants working abroad died in the past three and half years due to work-related accidents, road accidents, suicides and murders (19); the majority of deaths occurred in the Middle East (350 in Saudi Arabia; 306 in Qatar; and 125 in UAE and 441 in Malaysia). It has been suggested that most deaths occur due to a lack of awareness of local conditions among migrant workers and their inability to understand local languages; some fatalities could have been avoided by predeparture orientation classes on the workplace and road safety and on ways to deal with adverse climatic conditions (19).

Despite all these, there have been very few studies on the health-related accident status of migrant workers and none on male Nepalese migrant workers in the construction and factory industries of Qatar, Saudi Arabia and Malaysia. Consequently, this gives credence to the focus of this research in these countries and to assess the extent of workplace accidents in these risky industries.

\section{Methods}

Using a questionnaire, this cross-sectional study examined the perceived health risks and accidents at work for Nepalese construction and factory workers (over the age of 18 years) who had worked in Malaysia, Qatar and Saudi Arabia for over six months. The questionnaire was designed and piloted prior (20) to the main study. Data were collected by one of the authors (PA) and a native speaker, in Nepal during 2011 from a total of 403 migrants. The questionnaire was self-administered by those migrant workers who were literate and administered by PA for those workers who were illiterate. Male respondents were approached at Nepal's international airport and nearby accommodation, and selected using a convenience sampling method (21). The questionnaire included questions on health and lifestyle, working and living conditions and the use of health services in the previous 12 months (=recall period). Many of these questions had previously been used in other validated questionnaire studies, e.g. a health and lifestyle survey of Nepalese migrants in UK (22); a social survey of Chinese migrants and views on their work, education, and living conditions in Russia (23); and the Vietnam migration survey (24).

Additional questions were identified based on a review of the literature and were incorporated into the final questionnaire. Researchers with similar professional backgrounds were requested to provide feedback to improve the research questionnaire. Informed consent was obtained verbally and confidentiality was guaranteed as identifiers were removed.

Self-reported and perceived health risks, and migrant workers having accidents at work, were the main outcomes and coded as 'yes-no' answers in SPSS (version 18.0) subsequently were cross-tabulated against exploratory factors such as demographic and socio-economic characteristics and participants' health and lifestyle. Descriptive statistical techniques were applied and the outcomes used in logistic regression analyses. Multivariate logistic regression analyses were applied to find out which factors were significantly associated with accidents at work and perceived health risks when adjusting for other variables. For the analysis, independent variables were added in blocks of demographic, socio-economic, type of job, country of work, health and lifestyle characteristics. Ethical approval was granted by the Nepal Health Research Council (Ref no: 462 and 1190).

\section{Results}

Characteristics of Nepalese male migrant worker respondents Study participants $(n=423)$ were approached at the research site in Nepal. The vast majority ( $\mathrm{n}=403$ or $95.0 \%)$ agreed to participate and completed the survey questionnaire and those responses were included for analysis. Those twenty migrant workers declining appeared generally too busy to undertake the survey.

Forty six percent of respondents were aged between 20-29 years. Twenty seven percent of respondents originated from a higher caste (Brahmin/Chhetri) and nearly all (91\%) were married. Almost two-thirds of respondents were satisfied with their living conditions in their host country. Nearly a quarter of respondents had no formal education and just under half had received primary education as their highest education level (Table 1).

The majority (69\%) of migrant workers had semi-skilled jobs (e.g. factory workers, carpenters and electricians) and the remainder had unskilled occupations e.g. labourer. Just over a fifth reported that their work environment was poor or very poor. About two-thirds of migrants were protected by employers' health insurance and almost three-quarters had registered with a doctor abroad. A quarter of respondents considered their diet poor or very poor. Two-thirds of the sample smoked and about half consumed alcohol regularly. Nearly all (93\%) respondents reported that they did not take exercise most days (Table 1). One in six (17\%) respondents reported they had experienced accidents and injuries (e.g., road accident, cuts, fall, heart attack etc.) at work. Approximately half (46\%) of the migrant workers perceived health risks at work and the risks, including hearing problems, vision problems, skin problems, muscular pain, injuries and heart disease.

Factors associated with perceived health risks and accidents at work

Multivariate logistic regression analysis indicated there were two key statistically significant variables associated with perceived health risks at work (Table 2); marital status and work environment. Marital status was significantly associated with perceived health risks $(\mathrm{P}=0.022)$ and unmarried respondents were significantly less likely $(\mathrm{OR}=0.4,95 \%$ confidence interval $[\mathrm{CI}]=0.1-0.9)$ to perceive health risks at work. Respondents who rated their work environment as poor or very poor were 2.5 times more likely ( $95 \% \mathrm{CI}=1.5-4.4)$ to perceive that they had health risks at work (Table 2 ).

In contrast, there were five key statistically significant variables associated with accidents at work: (a) age; (b) accommodation; (c) work environment; (d) country of work and (e) doctor registration. Interestingly, respondents aged 40 and above were four times more likely (95\% CI=1.7-9.7) to experience work-related accidents compared with those aged 20-29 years. Accommodation was significantly associated with accidents at work; respondents not satisfied with their accommodation were nearly twice as likely $(\mathrm{OR}=1.9,95 \% \mathrm{CI}=1.1-3.4)$ to experience accidents at work compared to those who were satisfied. There 
Table 1 Nepalese male migrant worker respondents (403) in the Middle East and Malaysia

Variables
Health Status
Good/fair
Poor/very poor
Mental health symptom in the last month
No
Yes
Age

350

20-29 years

30-39 years

$40+$ years

Ethnicity

Brahmins/Chhetri

Others (Gurung/Tamang/Magar/Rai/Limbu/ Newar/Sherpa/Tharu/Terai ethnic group etc.)

\section{Marital Status}

Married

Unmarried

Satisfaction with the accommodation abroad

Satisfied

Education

$\mathrm{Sec} / \mathrm{SLC} / \mathrm{HS}$ (RC)

Primary

None

Current occupation in host countries

Semi-skilled job

Unskilled job

Middle East

Duration of stay abroad

$<4$ years $(\mathrm{RC})$

$\geq 4$ years

Work hours (average per week)

$\leq 70$ hours (RC)

$>70$ hours

Has health insurance

Has doctor registration

Perceives himself to have a health risk at work

Diet perceived to be

Good/fair

Very poor/poor

Currently consumes alcohol

Takes part in exercise most days

\section{$\%$}

Notes: HS- Higher Secondary (including College \& University); RC- Reference Category; Sec- Secondary; SLC- School Leaving Certificate 
is a strong and significant association between perceptions of the work environment and accidents at work. Respondents who reported their work environment as poor or very poor were 3.5 times more likely (95\% CI=1.8-6.7) to experience work-related accidents compared to those who reported a very good/good or fair working environment. Similarly, respondents who worked in the Middle East were 3.6 times more likely (95\% CI=1.58.5) to experience work-related accidents compared to those respondents who worked in Malaysia. Respondents not registered with a doctor were significantly less likely $(\mathrm{OR}=0.3,95 \% \mathrm{CI}=0.1$ $0.7)$ to experience a work-related accident compared with those who had registered (see Table 2).

\section{Discussion}

Work-related accidents

This study found that almost $17 \%$ of Nepalese migrant workers had experienced work-related accidents in Qatar, Saudi Arabia and Malaysia. This prevalence of work-related accidents is lower than that recorded in a previous study (25\%) among Nepalese migrants working in the Gulf-countries (7) and among Nepalese factory workers (22\%) in Nepal (25). Although the accident rate reported in this study is comparable to the findings of general studies among construction workers in developed countries such as the USA (20\%), Australia (17\%) and New Zealand (14\%) (26), it is higher than that recorded among manufacturing workers in Australia (10\%) and New Zealand (9\%) (26). Of course, as this study interviewed returnees to Nepal its prevalence does not include fatal accidents. Nevertheless, there are five key statistically significant variables (discussed below) associated with accidents at work: the age of the workers; their satisfaction with accommodation in their host country; perceived work environment; country of work; and registration with a doctor.

Age and accidents at work

The results of this study indicate that older migrants (40+ years) were four times more likely to have workplace-related accidents than younger age groups. It is known that most experienced worker are older people. Older workers having worked more years and hence having more exposure increasing the risk of an accident $(32,33)$. Older age as a risk factor for workplace accidents has been identified by other studies $(7,26,27)$. However, findings to the contrary, i.e. younger age groups $(<30$ years) are more likely to experience work-related injuries, have also been reported $(28,29)$. Most participants in this study were classed as unskilled or semi-skilled, and had been 'on the job' for relatively short periods of time, although all had been

\begin{tabular}{|c|c|c|c|c|c|c|}
\hline \multirow{2}{*}{ Variable } & \multicolumn{3}{|c|}{ Accidents at work } & \multicolumn{3}{|c|}{ Perceived health risks } \\
\hline & Odds ratio (95\% CI) & & p-value & Odds ratio (95\% CI) & \multicolumn{2}{|r|}{ p-value } \\
\hline \multicolumn{7}{|l|}{ Demographic characteristics } \\
\hline Age & & 0.007 & & & & \\
\hline 20-29 years (RC) & 1.0 & & & 1.0 & & \\
\hline $30-39$ years & $1.6(0.8-3.3)$ & 0.161 & & $0.9(0.5-1.4)$ & 0.572 & \\
\hline $40+$ years & $4.0(1.7-9.7)$ & 0.002 & & $0.6(0.3-1.1)$ & 0.102 & \\
\hline \multicolumn{7}{|l|}{ Ethnicity } \\
\hline Brahmins/Chhetri (RC) & 1.0 & & & 1.0 & & \\
\hline Others & $0.9(0.5-2.0)$ & 0.990 & & $1.2(0.7-2.0)$ & 0.425 & \\
\hline \multicolumn{7}{|l|}{ Marital Status } \\
\hline Married (RC) & 1.0 & & & 1.0 & & \\
\hline Unmarried & $0.9(0.3-3.0)$ & 0.828 & & $0.4(0.1-0.9)$ & 0.022 & \\
\hline \multicolumn{7}{|l|}{$\begin{array}{l}\text { Satisfaction with the accomo- } \\
\text { dation abroad }\end{array}$} \\
\hline Satisfied (RC) & 1.0 & & & 1.0 & & \\
\hline Not satisfied & $1.9(1.1-3.4)$ & 0.034 & & $1.5(0.9-2.3)$ & 0.103 & \\
\hline \multicolumn{7}{|l|}{ Education } \\
\hline Sec/SLC/HS (RC) & 1.0 & & & 1.0 & & \\
\hline Primary & $1.5(0.7-3.1)$ & 0.298 & & $1.2(0.7-2.1)$ & 0.473 & \\
\hline None & $0.8(0.3-2.0)$ & 0.595 & & $0.8(0.4-1.6)$ & 0.524 & \\
\hline \multicolumn{7}{|c|}{ Occupation and socio-economic characteristics } \\
\hline \multicolumn{7}{|l|}{$\begin{array}{l}\text { Current occupation in host } \\
\text { countries }\end{array}$} \\
\hline Semi-skilled job (RC) & 1.0 & & & 1.0 & & \\
\hline Unskilled job & $0.6(0.3-1.2)$ & 0.154 & & $1.3(0.7-2.2)$ & 0.397 & \\
\hline \multicolumn{7}{|l|}{ Work environment } \\
\hline Very good/good/fair (RC) & 1.0 & & & 1.0 & & \\
\hline Poor/very poor & $3.5(1.8-6.7)$ & $<0.001$ & & $2.5(1.5-4.4)$ & 0.001 & \\
\hline \multicolumn{7}{|l|}{ Country of work } \\
\hline Malaysia RC) & 1.0 & & & 1.0 & & \\
\hline Middle East & $3.6(1.5-8.5)$ & 0.004 & & $1.7(0.9-3.1)$ & 0.074 & \\
\hline
\end{tabular}


Duration of stay abroad

\begin{tabular}{|c|c|c|c|c|}
\hline$<4$ years $(\mathrm{RC})$ & 1.0 & & 1.0 & \\
\hline$>=4$ years & $0.6(0.3-1.2)$ & 0.129 & $0.8(0.5-1.2)$ & 0.300 \\
\hline $\begin{array}{l}\text { Work hours (average per } \\
\text { week) }\end{array}$ & & & & \\
\hline$<=70$ hours $(\mathrm{RC})$ & 1.0 & & 1.0 & \\
\hline$>70$ hours & $1.6(0.8-3.2)$ & 0.147 & $1.2(0.7-1.2)$ & 0.455 \\
\hline $\begin{array}{l}\text { Income in Nepalese Rup } \\
\text { (per annum) }\end{array}$ & & & & \\
\hline$>150000(\$ 1701)(\mathrm{NC})$ & 1.0 & & 1.0 & \\
\hline$>=150000(\$ 1701)$ & $0.9(0.5-1.8)$ & 0.836 & $0.2(0.6-1.5)$ & 0.821 \\
\hline Health insurance & & & & \\
\hline Yes (RC) & 1.0 & & 1.0 & \\
\hline No & $1.4(0.7-2.8)$ & 0.321 & $0.9(0.6-1.6)$ & 0.795 \\
\hline Yes (NC) & 1.0 & & 1.0 & \\
\hline No & $0.3(0.1-0.7)$ & 0.003 & $1.6(0.9-2.7)$ & 0.114 \\
\hline Health and lifestyle char & tics & & & \\
\hline Diet & & & & \\
\hline Good/fair (RC) & 1.0 & & 1.0 & \\
\hline Very poor/poor & $0.6(0.3-1.2)$ & 0.166 & $1.4(0.8-2.3)$ & 0.196 \\
\hline Current smoking status & & & & \\
\hline Non-smoker (RC) & 1.0 & & 1.0 & \\
\hline Smoker & $0.7(0.4-1.7)$ & 0.228 & $0.7(0.4-1.1)$ & 0.123 \\
\hline $\begin{array}{l}\text { Current alcohol consum } \\
\text { status }\end{array}$ & & & & \\
\hline $\begin{array}{l}\text { Take part in exercise mo } \\
\text { days }\end{array}$ & & & & \\
\hline Yes (RC) & 1.0 & & 1.0 & \\
\hline No & $2.8(0.6-13.3)$ & 0.197 & $1.9(0.8-4.6)$ & 0.155 \\
\hline Nagelkerke R Square & 0.219 & & 0.166 & \\
\hline
\end{tabular}

Notes: HS- Higher Secondary (including College and University); RC- Reference Category; Sec- Secondary; SLC- School Leaving Certificate; Semi-skilled jobs with a certain level of skills including factory workers, plumbers, carpenters, painters, bricklayers, electrician, supervisor etc.

working more than six months in their roles. It is therefore likely that older Nepalese migrant workers in this study had not been able to accumulate the necessary additional skills compared to younger workers. This is counter intuitive, but the underlying explanations are, first, that older workers abroad do not bring with them skills from Nepal that give them an advantage over younger migrant workers. And secondly, that perhaps the jobs abroad are either very different from what they have done in the past in Nepal and/or require such a low skill level that there is little opportunity to learn new skills.

Older workers may also have had to cope with physiological changes associated with ageing. It is known that muscle strength starts to decline with increasing age $(30,31)$. Therefore, the increased risk of having an accident for older migrants, especially among those aged $40+$ years could be due to physiological changes associated with ageing. Further, older age groups might have additional risk factors that make them more prone to accidents $(32,33)$. In this study, most older migrant workers are married and have greater family responsibilities and could therefore be experiencing more anxiety. This could be another reason for them being more prone to work-related accidents than younger workers.

Satisfaction with accommodation and accidents at work

The occurrence of work-related accidents is significantly related to satisfaction with accommodation in the country of work. Poorer accommodation may lead to poorer sleep or rest and people may not be as alert at work compared with those wellrested. Work-related accidents associated with sleep disturbance are well documented in the literature $(34,35)$.

Work environment and accidents at work

The work environment is significantly associated with accidents at work. People who perceive their work environment as poor or very poor are 3.5 times more likely to report accidents than those who perceived their work environments to be good or very good. Work-related accidents and injuries associated with a poor work environment are well documented in the media $(16,36)$. Importantly, a poor work environment is a well-recognised risk factor for work-related accidents in a number of Nepalese $(7,37$, 
38 ) and non-Nepalese studies $(15,39)$. Studies also found that a poor work environment, including an absence of safety measures and equipment, incorrect operating procedures, inadequate hazard awareness and insufficient use of protective equipment, results in more accidents and disability, mainly in construction and manufacturing industries $(3,15)$. Proper implementation of safety regulations at industrial sites and making the work environments safer should therefore be a priority for employers and policy makers $(40,41)$. Additionally, workers should be trained adequately in their jobs as well as in the application of any safety measures.

\section{Doctor registration and accidents at work}

Migrants, who are not registered with a doctor are less likely to report work-related accidents compared to those who do register. The first possible explanation for this could be that those who experience accidents register at the time of the accident when attending clinics or doctors surgeries. A second explanation is that those working for companies with safer working methods are more likely to be given insurance coverage $(42,43)$ e.g. migrant workers who are covered by health insurance are much more likely to be registered with a doctor and so have easier access to one. Conversely, workers who are not registered with a doctor may have used self-medication and/or home treatment techniques in their host country (44). This explanation would only explain some of the minor accidents that people may have 'forgotten' to report in the questionnaire, so called underreporting (45). Some of the perceived under-reporting might also be due to misconceptions and misunderstandings as to what constitutes an accident or workers hiding the fact that they were involved in an accident due to fear of losing their job (45).

\section{Work location and accidents at work}

Migrant workers who worked in Qatar and Saudi Arabia were 3.6 times more likely to experience work-related accidents than those working in Malaysia. The possible explanation for these higher accident rates in the Middle East is undoubtedly due to the nature of the job, work environment and health and safety at work. Nepalese people in the Middle East worked in building and construction, whereas those in Malaysia worked in factories. The literature on migrant workers indicates that the construction industry is a very dangerous business globally and compared to other industries $(14,17,25,46)$. The second possible reason for higher numbers of accidents in the Middle East could be due to heat exposure. Many migrant workers in the Middle East work outside where they experience very high day-time temperature, which is generally recognised in the literature as a risk factor (7, 47). Similarly, a third possible explanation for higher accident rates could be the influence of a difference in health and safety standards in these two different locations (48). This would suggest that Malaysia has higher health and safety standards, but there is no available published evidence to back up this assertion.

\section{Perceived health risks}

In the multivariate analysis, perceived health risk at work in this study was associated with marital status and the work environment. Unmarried people were significantly less likely ( $\mathrm{OR}=0.4,95 \% \mathrm{CI}=0.1-0.9)$ to perceive health risks at work. One possible reason behind this may be that they simply perceived fewer risks because they had fewer social responsibilities if something went wrong. The results of this study resonate with those of previous studies $(49,50)$. Similarly, workers rating their work environment as poor were two-and-a-half times more likely to perceive health risks at work than those who rated their work environment as good. Migrants working in poor environments, e.g. working long hours, with no safety training and communication difficulties at work (either in the host language or in English), are more likely to experience health risks at work. Associations between working conditions (i.e. long working hours, language problems, lack of safety training) and health problems, including accidents at work are well documented in the literature $(3,51-53)$.

\section{Strengths \& limitations}

This cross-sectional study is still the only one of its kind on the target population of male Nepali migrant workers. The two key weaknesses of this study are convenience sampling frame and the study location, i.e. in Nepal rather than host countries. As attempts to conduct the study in Qatar and Saudi Arabia were unsuccessful and a true sampling frame of returning workers to Nepal was impossible, this study had to use a convenience sampling frame. The lack of access for this research in the Middle East is regrettable, but understandable as it does not show the receiving countries in a good light.

\section{Conclusions}

Almost one-fifth of respondents in this study experienced workrelated accidents. Older workers are four times more likely than younger workers to report having had accidents at work, which contradicts some of the literature (7, 26-29). Workers who report poor living and working conditions are more likely to report accidents and injuries. The occurrence of workplace accidents is therefore strongly associated with perceptions of their accommodation and the work environment. Migrants who work in Qatar and Saudi Arabia in the construction industry are three times more likely to experience workplace accidents than those working in a Malaysian factory.

It is, therefore, argued that to reduce the health risks of workers in host countries the Government of Nepal should ensure that migrants are offered compulsory health insurance by the companies they work for, particularly in Middle Eastern destinations. Mandatory pre-departure health and safety training with refresher sessions on arrival are also strongly recommended.

\section{Acknowledgements}

Our sincere appreciation goes to all the study participants. This study was partially funded by Bournemouth University, UK and the Open Society Foundation.

\section{Compliance with Ethical Standards}

Funding: This study was partially funded by Open Society Foundation and a Bournemouth University graduate school travel award.

Conflict of Interest: Author A declares that he has no conflict of interest. Author B declares that she has no conflict of interest. Author C declares he has no conflict of interest. Author D declares he has no conflict of interest.

Ethical approval: All procedures performed in studies involving human participants were in accordance with the ethical standards of the institutional and/or national research committee and 
with the 1964 Helsinki declaration and its later amendments or comparable ethical standards. Ethical approval was granted by Nepal Health Research Council (Ref no: 462 and 1190).

Informed consent: Verbal and/or written informed consent was obtained from all individual participants included in the study.

\section{References}

1. International Organisation for Migration. World migration report 2010; the future of migration: building capacities for change. Geneva; 2010. Available at: http://publications.iom.int/bookstore/free/WMR_2010_ENGLISH.pdf Accessed on $15 / 11 / 2015$

2. Amuedo-Dorantes C, Borra C. On the differential impact of the recent economic downturn on work safety by nativity: the Spanish experience. IZA Journal of Migration. 2013;2:4.

3. Schenker MB. A global perspective of migration and occupational health. American Journal of Industrial Medicine. 2010;53:329-37.

4. Rosano A, Ronda E, Benavides FG, Cacciani L, Baglio G, Spagnolo A. Workrelated health problems among resident immigrant workers in Italy and Spain. Italian Journal of Public Health. 2012;9 (3):68-74.

5. Shrestha R. Half of Nepali households have member working abroad: Survey. Kathmandu Post (28 June). 2011. Available at: http://www.ekantipur.com/thekathmandu-post/2011/06/28/money/half-of-nepali-households-have-memberworking-abroad-survey/223411.html Accessed 10/01/2016

6. Baruah N, Tuladhar S. The challenge for Nepal's migrant workers, Nepalese citizens are increasingly moving abroad-particularly to Gulf countries-to find work. Will their rights be protected? The Diplomat (online newspaper). 2012. Available at: http://thediplomat.com/2013/10/the-challenge-for-nepals-migrantworkers/ Accessed 2/2/2017

7. Joshi S, Simkhada P, Prescott GJ. Health problems of Nepalese migrants working in three Gulf countries. BMC International Health \& Human Rights. 2011;11:3.

8. Rauniyar I. No state for migrant workers. eKantipur (5 Dec.). 2013. Available at: http://www.malaysia-today.net/malaysia-is-worse/ Accessed on 12/03/2016

9. Kollmair M, Manandhar S, Subedi B, Thieme S. New figures for old stories: migration and remittances in Nepal. Migration Letters. 2006;3(2):151-160.

10. Eileen NG. Suicide rate among Nepali workers in Malaysia "high", Nepal paper reports. The Malaysia Insider (06 Oct). 2013. Available at: http://www. themalaysianinsider.com/print/malaysia/suicide-rate-high-among-nepaliworkers-in-malaysia-nepal-paper-reports Accessed on 20/11/2015

11. Global Knowledge Partnership on Migration and Development (KNOMAD). Migration and Remittances Factbook 2016 (3rd edn), World Bank Group. 2016. Available at: https://siteresources.worldbank.org/INTPROSPECTS/ Resources/334934-1199807908806/4549025-1450455807487/Factbookpart1.pdf Accessed on 12/4/17

12. Keane D, McGeehan D. Enforcing migrant workers right in the United Arab Emirates. International Journal on Minority and Group Rights. 2008;15:81-115. 13. Bergdahl IA, Toren K, Eriksson K, Hedlund U, Nilsson T, Flodin R, Jarvholm B. Increased mortality in COPD among construction workers exposed to inorganic dust. European Respiratory Journal. 2004;23:402-406.

14. Gürcanli GE, Müngen U, Akad M. Construction equipment and motor vehicle related injuries on construction sites in Turkey. Industrial Health. 2008;46:375388.

15. Cheng C-W, Wu T-C. An investigation and analysis of major accidents involving foreign workers in Taiwan's manufacture and construction industries. Safety Science. 2013; 57:223-235.

16. Hadid D. Rising suicide cases among Nepalese cause for concern. Gulf News (19 Dec). 2005. Available at: http://.com/news/gulf/uae/general/rising-suicidecases-among-nepalese-cause-for-concern-1.308513 Accessed on 10/03/2016 17. Murty OP, Chung BSK, Yin LY, Loo TC, Nurul IP. Pattern of injuries in fatal accidents of construction workers: a retrospective study of 10 years (1996-2005).
Malaysian Journal of Forensic Pathology and Science.2006;1 (1):44-57.

18.The Himalayan Times. Over 800 workers died abroad, 160 suicides, No figures from Iraq, Afghanistan in absence of Nepali missions. The Himalayan Times, (13 Jan). 2011. Available at: http://www.thehimalayantimes.com/fullNews.php?head line $=$ Over $+800+$ workers + died + abroad $\% 2 C+160+$ suicides $+\&$ NewsID $=272935$

19. Sedhai R. Internal report: 1,357 migrant workers 'died' in 3-and-a-half yrs. The Kathmandu Post (12 Jan.). 2012. Available at: http://kathmandupost. ekantipur.com/printedition/news/2012-01-11/internal-report-1357-migrantworkers-died-in-3-and-a-half-yrs.html. Accessed on 21/02/2016

20. van Teijlingen E, Hundley V. The importance of pilot studies. Nursing Standard. 2002;16:33-36.

21. Bowling A. Research methods in health: investigating health and health services. 2nd edition. Buckingham: Open University Press. 2002.

22. Adhikary P, Simkhada P, van Teijlingen E, Raja A. Health and life style of Nepalese migrants in UK. BMC International Health and Human Right. 2008;8:6. 23. Larin AG. Chinese Migrants: Their views on the work, education, and living conditions in Russia. Studies on Russia Economic Development. 2009; 20 (3):326341. 24.GSO. The 2004 Viet Nam migration survey: migration and health. Hanoi: General Statistics Office \& United Nations Population Fund. 2004.

25. Kumar PR, Nirmal R, Ojha S, Anuj M. Study on 100 industrial accident cases in Nepal: type and severity of the injuries and its predisposing factors. Industrial Accident Cases in Nepal. 2003;1:19-24.

26. Feyer A-M, Williamson AM, Stout N, Driscoll T, Usher H, Langley JD. Comparison of work related fatal injuries in the United States, Australia, and New Zealand: method and overall findings. Injury Prevention. 2001;7:22-28.

27. Jones MK, Latreille PL, Sloane PJ, Staneva AV. Work-related health in Europe: are older workers more at risk? Discussion paper 6044. 2011. Available at: https:// www.econstor.eu/dspace/bitstream/10419/58567/1/689691041.pdf Accessed on $15 / 03 / 2016$

28. Nij ET, Burdorf A, Parker J, Attfield M, van Duivenbooden C, Heederik D. Radiographic abnormalities among construction workers exposed to quartz containing dust. Occupational and Environmental Medicine. 2003;60:410-417.

29. Tadesse T, Kumie A. Prevalence and factors affecting work-related injury among workers engaged in small and medium-scale industries in Gondar wereda, north Gondar Zone, amhara regional state, Ethopia. Ethopian Journal of Health Development. 2007;21 (1):25-34.

30. Frontera WR, Hughes VA, Lutz KJ, Evans WJ. A cross-sectional study of muscle strength and mass in 45 to 78 years old men and women. Journal of Applied Physiology. 1991;71(2):644-650.

31. Lindle RS, Metter EJ, Lynch NA, Fleg JL, Fozard JL, Tobin J et al. Age and gender comparisions of muscle strength in 654 women and men aged 20-93 years. Journal of Applied Physiology. 1997;83(5):1581-1587.

32. Arndt V, Rothenbacher D, Daniel U, Zschenderlein B, Schuberth S, Brenner H. Construction work and risk of occupational disability: a ten year follow up of 14474 male workers. Occupational and Environmental Medicine. 2005;62:559566.

33. Deacon C, Smallwood J, Haupt T. The health and well-being of older construction workers. International Congress Series. 2005;1280:172-177.

34. Åkerstedt T, Fredlund P, Gillberg M, Jansson B. A prospective study of fatal occupational accidents-relationship to sleeping difficulties and occupational factors. Journal of Sleep Research. 2002;11:69-71.

35. Sandberg JC, Talton JW, Quandt SA, Chen H, Weir M, Doumani WR et al. Association between housing quality and individual health characteristics on sleep quality among Latino farm-workers, Journal of Immigrants Minor Health. 2014;16(2):265-272.

36. Nepalnews. 24 Nepalis die in one month in Qatar. Nepal news (25 June). 2009. Available at: http://test.nepalnews.com/index.php/economy/19-news/ general/168-24-nepalis-die-in-onemonth-in-qatar

37. Gurung G, Adhikari J. The prospects and problems of foreign labour migration; in: Ahn, P.(ed.) Migrants Workers and Human Rights, Out Migration from South Asia, Geneva: ILO. 2004;101-130. 
38. NIDS. State of migrants health 2005. Nepal country report. Nepal institute of development studies, Kathmandu, Nepal. 2006.

39. Abdul-Aziz A-R. Bangladeshi migrant workers in Malaysia’s construction sector. Asia-Pacific Population Journal. 2001;16(1):3-22.

40. Benach J, Muntaner C, Delclos C, Menéndez M, Ronquillo C. Migration and "low-skilled" workers in destination countries. PLos Medicine. 2011;8:6. Available at: http://www.ncbi.nlm.nih.gov/pmc/articles/PMC3110069/ Accessed on $29 / 11 / 2015$

41. Giuffrida A, Fiunes R, Savedoff W. Occupational risks in Latin America and the Caribbean: economic and health dimensions. Health Policy and Planning. 2002;17(3):235-246.

42. Berdahl TA, Zodet M. Medical care utilization for work-related injuries in the United States 2002-2006. Medical Care. 2010;48(7):645-651.

43. Mou J, Cheng J, Zhang D, Jiang H, Lin L, Griffiths SM. Health care utilisation amongst Shenzhen migrant workers: does being insured make a difference? BMC Health Services Research. 2009;9:214.

44. Naing T, Geater A, Pungrassami P. Migrant workers' occupation and healthcare-seeking preferences for TB-suspicious symptoms and other health problems: a survey among immigrant workers in Songkhla province, southern Thailand. BMC International Health and Human Rights. 2012;12:22.

45. Pransky G, Snyder T, Dembe A, Himmelstein. Under-reporting of workrelated disorders in the workplace: a case study and review of the literature. Ergonomics. 2010;42(1):171-182.

46. Shibani A, Saidani M, Alhajeri M. Health and safety influence on the construction project performance in United Arab Emirates (UAE). Journal of Civil Engineering and Construction Technology. 2013;4(2):32-44.

47. Bates GP, Miller VS, Joubert DM. Hydration Status of Expatriate Manual Workers During Summer in the Middle East. Annals of Occupational Hygiene. 2009;1-7.

48. Habib RR. Overview of the occupational safety and health situation in the Arab region. Beirut: ILO. 2007.

49. Halvani GH, Jafarinodoushan R, Mirmohammadi SJ, Mehrparvar AH. A survey on occupational accidents among construction industry workers in Yazd city Applying Time Series 2006-2011. Journal of Occupational Health Epidemiology. 2012;1:1-8.

50. Mohammad FI. Evaluation of occupational accidents and their related factors in Iranian Aluminum Company in 1999. Scientific Journal of Kurdistan University of Medical Sciences. 2001;19:18-23. (in Persian)

51. Dembe AE, Erickson JB, Delbos RG, Banks SM. The impact of overtime and long work hour on occupational injuries and illness: new evidence from the United States. Occupational Environmental Medicine. 2005;62:588-597.

52. Orrenius PM, Zavodny M. Do immigrants work in riskier jobs?. Demography. 2009; 46(3):535-551.

53. Virtanen M, Heikkila K, Jokela M, Ferrie JE, Batty GD, Vahtera J et al. Long working hours and coronary heart disease: a systematic review and meta analysis. American Journal of Epidemiology. 2012;176 (7):586-596. 